\title{
Xylan-degrading ability of thermophilic Actinobacteria isolated from soil in a geothermal area
}

\author{
MAZYTHA KINANTI RACHMANIA ${ }^{1, *}$, FITRIA NINGSIH ${ }^{1,2, *}$, PUTRI PRATIWI SETYANINGSIH ${ }^{\mathbf{1}}$, \\ WINDA AYU SYAFITRI ${ }^{1}$, DHIAN CHITRA AYU FITRIA SARI ${ }^{1,2}$, SHUHEI YABE ${ }^{3,4}$, AKIRA YOKOTA $^{3}$, \\ ARIYANTI OETARI ${ }^{1,2}$, WELLYZAR SJAMSURIDZAL ${ }^{1,2, \bullet}$ \\ ${ }^{1}$ Department of Biology, Faculty of Mathematics and Natural Sciences, Universitas Indonesia, J1. Prof. DR. Sudjono D. Pusponegoro, Kampus UI Depok, \\ Depok 16424, Indonesia. Tel.: +62-21-7270163, Fax.: +62-21-78849010 \\ ${ }^{2}$ Center of Excellence for Indigenous Biological Resources-Genome Studies, Faculty of Mathematics and Natural Sciences Universitas Indonesia, \\ Jl. Prof. DR. Sudjono D. Pusponegoro, Kampus UI Depok, Depok 16424, Indonesia. "email: sjwelly@ hotmail.com; sjwelly@ sci.ui.ac.id. \\ ${ }^{3}$ Department of Microbial Resources, Graduate School of Agricultural Sciences, Tohoku University, 468-1 Aoba, Aramaki, Aoba-ku, Sendai, Miyagi \\ 980-0845, Japan. \\ ${ }^{4}$ Hazaka Plant Research Center, Kennan Eisei Kogyo Co., Ltd., 44 Aza-Inariyama, Oaza-Ashitate, Murata-cho, Shibata-gun, Miyagi 989-1311, Japan. \\ *These authors had been contributed equally
}

Manuscript received: 15 October 2019. Revision accepted: 14 December 2019.

\begin{abstract}
Rachmania MK, Ningsih F, Setyaningsih PP, Syafitri WA, Sari DCAF, Yabe S, Yokota A, Oetari A, Sjamsuridjal W. 2020. Xylan-degrading ability of thermophilic Actinobacteria isolated from soil in a geothermal area. Biodiversitas 21: 144-154. This study was conducted to obtain the potential isolates of xylan-degrading thermophilic Actinobacteria. Seventeen isolates were obtained from the soil samples collected from Cisolok geysers in West Java, Indonesia. These isolates were screened for their xylan-degrading ability on minimal medium with the addition of $0.5 \%$ xylan as substrate, and were incubated at various temperatures for 7 days. A total of 15 , 14,4 , and 3 isolates showed a xylan-degrading ability at $45^{\circ} \mathrm{C}, 50^{\circ} \mathrm{C}, 55^{\circ} \mathrm{C}$, and $60^{\circ} \mathrm{C}$, respectively. The three isolates (SL1-2-R-2, SL12-R-3, and SL1-2-R-4) that showed xylan-degrading ability at $60^{\circ} \mathrm{C}$ on $0.5 \%$ xylan were further tested by using minimal medium with the addition of $0.1 \%$ RBB-xylan as a substrate. The results showed that these isolates were also able to utilized RBB-xylan at 45 to $60^{\circ} \mathrm{C}$. The xylanolytic activity of the crude enzymes from the three isolates on minimal medium containing $0.5 \%$ xylan or $0.1 \%$ RBBxylan as substrates, indicated that these isolates were able to produce extracellular xylanase. This study revealed that the soil of Cisolok geysers served as an ideal source for finding the thermophilic Actinobacteria which produced xylanase at high temperatures.
\end{abstract}

Keywords: Cisolok geysers, soil, thermophilic Actinobacteria, xylanase

\section{INTRODUCTION}

Phylum Actinobacteria is one of the largest taxonomic groups within the domain Bacteria, and it constitutes Gram-positive bacteria with high GC DNA content (Ventura et al. 2007). Most of the members of this phylum are mycelium-forming bacteria (Barka et al. 2016). The majority of Actinobacteria are soil inhabitants, and they contribute to the decomposition process and nutrient cycling (Goodfellow and Williams 1983). Actinobacteria are known to be potential producers of various secondary metabolites, such as antibiotics, enzymes, herbicides, and antifungal (Barka et al. 2016).

Thermophilic Actinobacteria are adapted to high temperatures ranges between 40 to $80^{\circ} \mathrm{C}$. Moreover, thermophilic Actinobacteria thrive in diverse environments, such as sea sediment, hydrothermal vents, desert, geothermal sites, and compost heaps. Their ability to survive under high temperatures is attributed to the stability of their cellular components, such as by production of specific enzymes (Shivlata and Satyanarayana 2015).

Thermophilic Actinobacteria play a major role in industrial fields due to their ability to produce various thermostable enzymes, such as amylase, cellulase, lipase, protease, and xylanase (Singh et al. 2013). In recent years, pulp and paper industries are faced an environmental problem due to their utilization of chlorinated organic substances which are toxic, persistent, and harmful to organisms and environments (Beg et al. 2001). Xylanases produced by microorganisms have gained great attention as an alternative substitution agent to toxic chorine chemicals used in pre-bleaching of kraft pulps process due to their environmentally friendly and economically cheap technologies (Walia et al. 2017). Consequently, the use of xylanases in several industrial processes has stimulated various researches that investigate the characteristics of xylanolytic enzymes (Beg et al. 2001).

Xylan is a major polysaccharide component of hemicellulose, which is found in lignocellulosic biomass of plant cell walls (Moreira and Filho 2016). Xylan consists of xylose units linked by $\beta-1,4$ glycosyl linkages (Singh et al. 2013). Complete degradation of xylan requires synergistic hydrolytic enzymes, including enzymes responsible for the degradation of xylan backbone and its various side chain groups (Kumar et al. 2018). Xylanases catalyze the hydrolysis of xylan by cleaving the $\beta-1,4$-xylosidic bonds in the backbone of xylan, which consists of xylose units (Kumar et al. 2018). Endo-xylanases (EC 3.2.1.8) and $\beta$ xylosidases (EC 3.2.1.37) are the major enzymes involved 
in xylan degradation (Juturu and $\mathrm{Wu}$ 2012). Thus, the extracellular endo-1,4- $\beta$-xylanase produced by bacteria could be detected by the presence of a clear zone around colonies grown on xylan-containing medium after being stained with Congo red (MacKenzie and Williams 1984).

Xylanases have been utilized in various industrial applications, e.g. bleaching in the paper industry, liquefaction of coffee mucilage, maceration of vegetable, extraction of pigments and flavors, bioremediation of agricultural wastes (Kulkarni et al. 1999), and saccharification of xylan (Juturu and Wu 2012). Most of these industrial processes require stable xylanases at high temperatures (Kumar et al. 2018); for example, the conversion of xylan into xylose during saccharification process occurs at $40-80^{\circ} \mathrm{C}$ (Juturu and $\mathrm{Wu} 2012$ ). Therefore, the findings of microorganisms that are able to produce stable and active xylanases at high temperatures will have a great impact on various industrial applications (Beg et al. 2001).

Production of thermostable xylanase has been reported in various genera of Actinobacteria, such as Actinomadura, Cellulosimicrobium, Streptomyces, and Thermobifida (Walia et al. 2017). Actinomadura xylanilytica is one of the members of the genus Actinomadura that can degrade xylan (Zucchi et al. 2013). However, thermophilic Actinobacteria are rarely explored due to the difficulties in isolation and maintenance. Consequently, thermophilic xylanase-producing Actinobacteria are still rarely reported (Singh et al. 2013).

Bacterial communities in geothermal areas in Indonesia are still rarely explored, although these communities are potential producers of thermostable enzymes. Cisolok geothermal area in West Java, Indonesia is one of potential habitat from where thermophilic bacteria can be isolated (Mawarid et al. 2016; Yokota et al. 2016; Ningsih et al. 2019). Yokota et al. (2016) have proposed a new species of thermophilic bacterium, namely Paenibacillus cisolokensis, isolated from litter of Cisolok geysers, which can hydrolyze various substrates, such as starch, xylan, and cellulose at temperature of $50^{\circ} \mathrm{C}$. Another thermophilic bacterium, Brevibacillus sp. UICC B-76, isolated from litter of Cisolok geysers, demonstrated xylanase, amylase, and cellulase activities at temperature of $50^{\circ} \mathrm{C}$ (Mawarid et al. 2016). Thus, the Cisolok geothermal area is a promising source of thermophilic enzyme producers.

In our previous study (Syafitri et al. 2019), we reported the growth and starch-degrading abilities from 17 Actinobacteria isolates obtained from soil of Cisolok geysers, West Java, Indonesia. A total of 17, 16, 6, and 5 isolates were able to grow at temperatures of $45,50,55$, and $60^{\circ} \mathrm{C}$, respectively, and 15 isolates showed starchdegrading ability at $45^{\circ} \mathrm{C}$. The results indicating that all of the investigated Actinobacteria isolates were thermophiles and showed amylolytic activity. Three potential isolates, designated SL1-2-R-2, SL1-2-R-3, and SL1-2-R-4, showed amylolytic activity at $60^{\circ} \mathrm{C}$ and were identified based on $16 \mathrm{~S}$ rRNA gene as Actinomadura keratinilytica. We also reported in a separate paper (Setyaningsih et al. 2019) the cellulose-degrading ability of those 17 Actinobacteria isolates, which showed that 15 out of 17 isolates were able to degrade carboxymethyl cellulose $(\mathrm{CMC})$ at $45^{\circ} \mathrm{C}$. The results also showed that three potential isolates (SL1-2-R-2, SL1-2-R-3, and SL1-2-R-4) were able to degrade both CMC and microcrystalline cellulose (MCC) substrates at $60^{\circ} \mathrm{C}$. However, the study of the xylan-degrading ability from these 17 thermophilic Actinobacteria isolates has not been performed yet.

Studies on thermophilic Actinobacteria community in geothermal areas in Indonesia not only can contribute to discovering the potential sources of thermostable enzymes but also expanding the knowledge on the diversity of thermophilic Actinobacteria in Indonesia. This study aimed to obtain the potential isolates of xylan-degrading thermophilic Actinobacteria isolated from soil of Cisolok geysers, a geothermal area in West Java, Indonesia.

\section{MATERIALS AND METHODS}

\section{Microorganisms}

Seventeen thermophilic Actinobacteria isolates and the type strain of Actinomadura keratinilytica NBRC $105837^{\mathrm{T}}$ were used in this study. Seventeen Actinobacteria isolates were obtained from 5 soil samples collected from 3 locations around Cisolok geysers, a geothermal area in West Java, Indonesia. The information on the soil samples, sampling sites, and isolates deposition in Culture Collection have been reported in our previous study (Syafitri et al. 2019). The type strain of Actinomadura keratinilytica NBRC $105837^{\mathrm{T}}$ was obtained from NITE Biological Resource Center (NBRC) Culture Collection, Japan.

\section{Screening of xylan-degrading ability}

The 17 thermophilic Actinobacteria isolates were screened for xylan-degrading ability using xylan as substrate according to Meddeb-Mouelhi et al. (2014). Actinobacteria isolates were grown on minimal (Mm) agar plates with addition of $0.5 \%(\mathrm{w} / \mathrm{v})$ xylan. The $\mathrm{Mm}$ agar without addition of xylan was served as a control. The plates were incubated up to 7 days at temperatures of 45 , 50, 55, and $60^{\circ} \mathrm{C}$. Xylan hydrolysis was detected by flooding the plates with $0.2 \%(\mathrm{w} / \mathrm{v})$ Congo red solution and destained by two times washing with $1 \mathrm{M} \mathrm{NaCl}$ solution. The presence of a clear zone around the colonies indicated a positive result for xylan-degrading ability. The experiment was carried out in triplicates.

The xylan-degrading ability of the potential thermophilic Actinobacteria isolates and the type strain Actinomadura keratinilytica NBRC $105837^{\mathrm{T}}$ were tested by using $0.5 \% \quad(w / v)$ xylan and $0.1 \% \quad(w / v)$ RBB-xylan (Birchwood xylan dyed by Remazol Brilliant Blue R, Azoxylan, Megazyme) as substrates, according to the methods described by Meddeb-Mouelhi et al. (2014) and Jeffrey et al. (2011) respectively. The isolates were grown on $\mathrm{Mm}$ agar plates with the addition of $0.5 \%$ xylan and $0.1 \%$ RBBxylan, incubated at temperatures of $45,50,55$, and $60^{\circ} \mathrm{C}$ up to 7 and 3 days, respectively. The experiment was carried out in duplicates.

Examination of extracellular xylanase production was performed according to Yabe S 2019, pers. com. and 
Ningsih F 2019, pers. com. The potential isolates and type strain were grown on modified Bennett's (Jones 1949) broth, with glucose replaced by glycerol, and incubated at $45^{\circ} \mathrm{C}$ for 7 days as pre-inoculated culture. Cell biomass was harvested by centrifugation at $8,000 \mathrm{rpm}, 4^{\circ} \mathrm{C}$ for 10 minutes, and washed twice with sterile deionized water. Cell biomass was inoculated into $\mathrm{Mm}$ broth containing $0.5 \%$ xylan and incubated at $45^{\circ} \mathrm{C}$ for 7 days as main culture. Centrifugation was performed to separate cell biomass and culture supernatants containing crude enzyme. Extracellular xylanase production was examined by placing $50 \mu \mathrm{l}$ of culture supernatants on the surface of Mm plates containing $0.5 \%$ xylan and $0.1 \%$ RBB-xylan, followed by incubation at various temperatures $\left(45,50,55\right.$, and $\left.60^{\circ} \mathrm{C}\right)$ for 24 hours. Congo red staining method was performed for detection of extracellular xylanase production on $0.5 \%$ xylan. The formation of clear zone indicated positive results for xylanolytic activity.

\section{Phylogenetic analyses}

The operational taxonomic units (OTUs) and their accession numbers of the $16 \mathrm{~S}$ rRNA gene sequences in the international DNA database used in the phylogenetic analyses are presented in Table 1. Multiple alignments of the 16S rRNA gene sequences was carried out using MEGA 7.0.26 software (Kumar et al. 2016) and all gap positions were excluded. The phylogenetic tree was constructed using the neighbor-joining (NJ) (Saitou and Nei 1987), maximum likelihood (ML) (Felsenstein 1981), and minimum evolution (ME) (Rzhetsky and Nei 1992) methods. The Kimura two-parameter substitution model was used to obtain the evolutionary distances (Kimura 1980). The robustness value of individual branches of the phylogenetic tree was obtained using bootstrap analysis with 1,000 replications (Felsenstein 1985).

Table 1. The OTUs and their accession numbers of the 16S rRNA gene sequences used in the phylogenetic analyses.

\begin{tabular}{|c|c|}
\hline Strain & Accession number \\
\hline Actinomadura barringtoniae GKU $128^{\mathrm{T}}$ & KF667497 \\
\hline A. fibrosa ATCC $49459^{\mathrm{T}}$ & AF163114 \\
\hline A. fulvescens IFO $14347^{\mathrm{T}}$ & U49005 \\
\hline A. gamaensis NEAU-Gz5 $5^{\mathrm{T}}$ & KT989505 \\
\hline A. geliboluensis $\mathrm{A} 8036^{\mathrm{T}}$ & HQ157187 \\
\hline A. hallensis $\mathrm{H} 647-1^{\mathrm{T}}$ & DQ076484 \\
\hline A. hibisca NBRC $15177^{\mathrm{T}}$ & BCRO01000158 \\
\hline A. keratinilytica $\mathrm{WCC}-2265^{\mathrm{T}}$ & EU637009 \\
\hline A. kijaniata $\mathrm{NBRC} 1422^{\mathrm{T}}$ & BCQR01000335 \\
\hline A. madurae DSM $43067^{\mathrm{T}}$ & X97889 \\
\hline A. miaoliensis $\mathrm{BC} 44 \mathrm{~T}-5^{\mathrm{T}}$ & EF116925 \\
\hline A. montaniterrae CYP1-1B ${ }^{\mathrm{T}}$ & LC126428 \\
\hline A. namibiensis DSM $44197^{\mathrm{T}}$ & AJ420134 \\
\hline A. nitritigenes DSM $44137^{\mathrm{T}}$ & AY035999 \\
\hline A. oligospora ATCC $43269^{\mathrm{T}}$ & AF163118 \\
\hline A. rhizosphaerae $\mathrm{SDA} 37^{\mathrm{T}}$ & LC369500 \\
\hline A. rubrobrunea NBRC $15275^{\mathrm{T}}$ & BCQU01000204 \\
\hline A. rudentiformis $\mathrm{HMC1}^{\mathrm{T}}$ & DQ285420 \\
\hline A. syzygii GKU $157^{\mathrm{T}}$ & KF667496 \\
\hline A. viridilutea IFO14480 ${ }^{\mathrm{T}}$ & D86943 \\
\hline A. xylanilytica $\mathrm{BK} 147^{\mathrm{T}}$ & FR692101 \\
\hline Streptosporangium album DSM $43023^{\mathrm{T}}$ & X89934 \\
\hline
\end{tabular}

\section{Observation of morphological properties of potential Actinobacteria isolates}

The potential Actinobacteria isolates were grown on modified Bennett's medium (Jones 1949), for 14 days at temperature of $45^{\circ} \mathrm{C}$. The modified Bennett's medium, with the addition of $2 \%$ agar (HiMedia) and $2 \%$ gellan gum (Wako) as solidifying agents, were used to observe substrate and aerial mycelia, respectively. The morphological properties of the potential Actinobacteria isolates were observed under a Hirox KH-8700 digital microscope (Hirox Co. LTD, Japan), and were compared with the species description provided in the Bergey's Manual of Systematic Bacteriology: The Actinobacteria, parts A and B (Goodfellow et al. 2012).

\section{RESULTS AND DISCUSSION}

\section{Screening of xylan-degrading ability}

In this study, 15, 14, 4, and 3 isolates showed xylandegrading ability at temperatures of $45,50,55$, and $60^{\circ} \mathrm{C}$, respectively. The results for screening of xylan-degrading ability from 17 thermophilic Actinobacteria isolates grown on $\mathrm{Mm}$ medium with the addition of $0.5 \%$ soluble xylan as substrate are shown in Table 2. The formation of clear zones around the colonies grown on $0.5 \%$ xylan following Congo red staining is shown in Figure 1. The formation of clear zone indicated the xylan-degrading ability of the colonies. According to MacKenzie and Williams (1984), the formation of clear zones on the screening medium was due to the production of extracellular xylanase. The binding interaction between polysaccharides and Congo red forms a red coloration. Xylanases play a role in the binding reaction as indicated by the formation of a clear zone, due to the hydrolysis of xylan into its oligomeric or monomeric units as a result of the $\beta-1,4$-xylan linkages cleavage.

Table 2. Xylan-degrading ability of the thermophilic Actinobacteria isolates grown on minimal medium containing $0.5 \%$ xylan as substrate at temperatures of $45,50,55$, and $60^{\circ} \mathrm{C}$ for 3 and 7 days of incubation.

\begin{tabular}{cccccccccc}
\hline \multirow{2}{*}{ No. } & \multirow{2}{*}{ Isolate } & \multicolumn{10}{c}{$\mathbf{4 5}^{\circ} \mathrm{C}$} & $\mathbf{5 0}^{\circ} \mathrm{C}$ & \multicolumn{3}{c}{$\mathbf{5 5}^{\circ} \mathrm{C}$} & \multicolumn{3}{c}{$\mathbf{6 0}^{\circ} \mathrm{C}$} \\
\cline { 3 - 10 } & & $\mathbf{3 d}$ & $\mathbf{7 d}$ & $\mathbf{3 d}$ & $\mathbf{7 d}$ & $\mathbf{3 d}$ & $\mathbf{7 d}$ & $\mathbf{3 d}$ & $\mathbf{7 d}$ \\
\hline 1 & SL1-1-R-2 & + & + & + & + & $*$ & $*$ & $\mathrm{n} / \mathrm{a}$ & $\mathrm{n} / \mathrm{a}$ \\
2 & SL1-1-R-4 & + & + & + & + & $*$ & $*$ & $\mathrm{n} / \mathrm{a}$ & $\mathrm{n} / \mathrm{a}$ \\
3 & SL1-1-R-7 & + & + & + & + & $*$ & $*$ & $\mathrm{n} / \mathrm{a}$ & $\mathrm{n} / \mathrm{a}$ \\
4 & SL1-1-R-8 & + & + & + & + & $*$ & $*$ & $\mathrm{n} / \mathrm{a}$ & $\mathrm{n} / \mathrm{a}$ \\
5 & SL1-2-R-2 & + & + & + & + & + & + & + & + \\
6 & SL1-2-R-3 & + & + & + & + & + & + & + & + \\
7 & SL1-2-R-4 & + & + & + & + & + & + & + & + \\
8 & SL2-2-R-1 & + & + & + & + & + & + & $*$ & $*$ \\
9 & SL2-2-R-12 & + & + & + & + & $*$ & $*$ & $\mathrm{n} / \mathrm{a}$ & $\mathrm{n} / \mathrm{a}$ \\
10 & SL2-2-R-15 & - & - & - & - & - & - & - & - \\
11 & SL3-1-R-14 & + & + & + & + & $*$ & $*$ & $*$ & $*$ \\
12 & SL3-1-R-16 & - & - & - & - & - & - & - & - \\
13 & SL3-2-R-5 & + & + & + & + & $*$ & $*$ & $\mathrm{n} / \mathrm{a}$ & $\mathrm{n} / \mathrm{a}$ \\
14 & SL3-2-R-17 & + & + & + & + & $*$ & $*$ & $\mathrm{n} / \mathrm{a}$ & $\mathrm{n} / \mathrm{a}$ \\
15 & SL3-2-R-18 & + & + & $*$ & $*$ & $*$ & $*$ & $\mathrm{n} / \mathrm{a}$ & $\mathrm{n} / \mathrm{a}$ \\
16 & SL3-2-R-33 & + & + & + & + & $*$ & $*$ & $\mathrm{n} / \mathrm{a}$ & $\mathrm{n} / \mathrm{a}$ \\
17 & SL3-2-R-37 & + & + & + & + & $*$ & $*$ & $\mathrm{n} / \mathrm{a}$ & $\mathrm{n} / \mathrm{a}$ \\
\hline
\end{tabular}

Note: (+) indicates positive result for xylan-degrading ability; (-) indicates negative result for xylan-degrading ability; $(*)$ indicates no growth; and (n/a) indicates that the experiment was not conducted. 
$45^{\circ} \mathrm{C}$

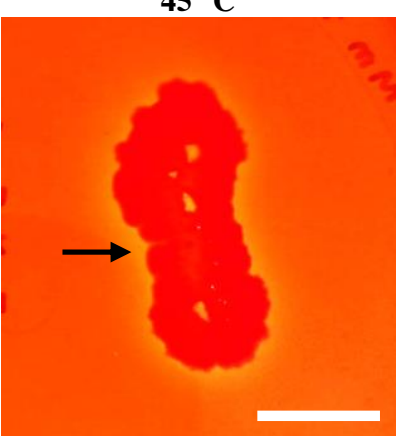

A

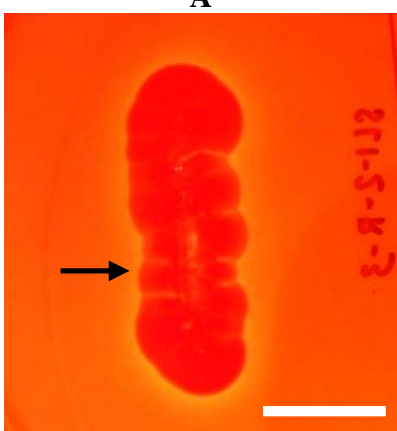

$\mathbf{E}$

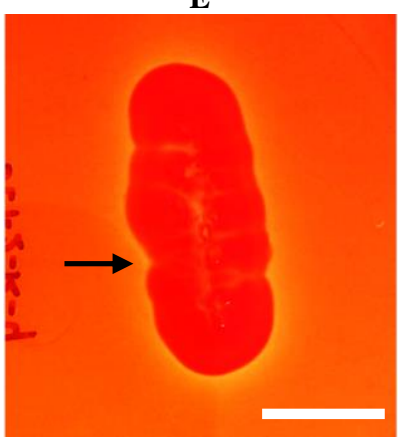

I
$50{ }^{\circ} \mathrm{C}$

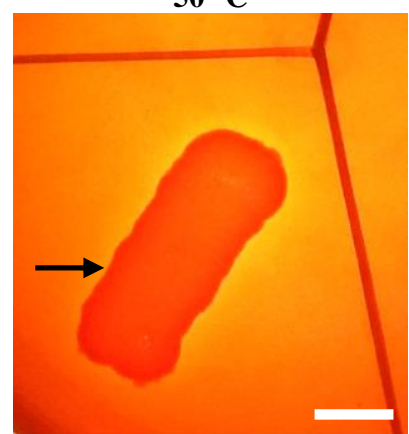

B

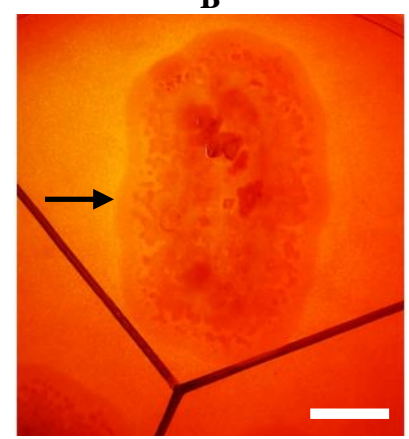

F

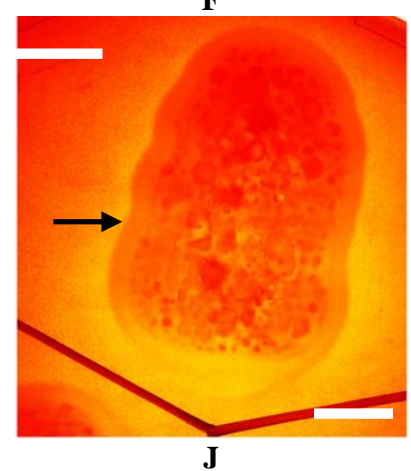

$55^{\circ} \mathrm{C}$

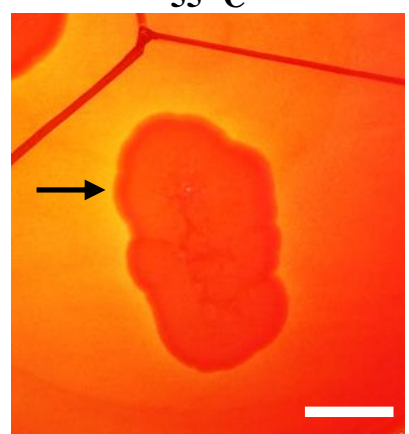

C

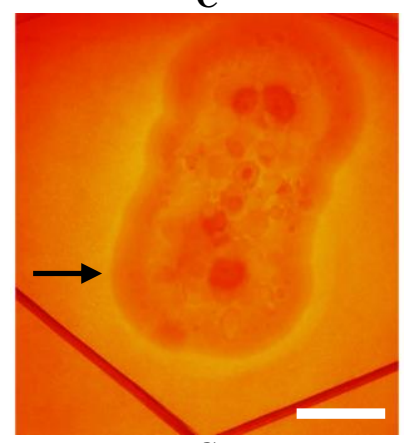

G

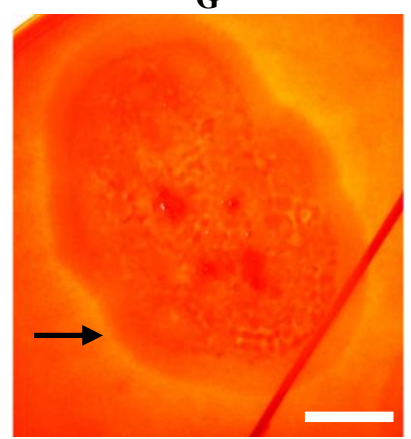

$\mathbf{K}$ $60^{\circ} \mathrm{C}$

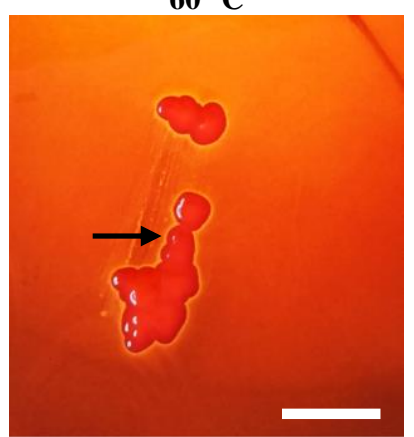

D

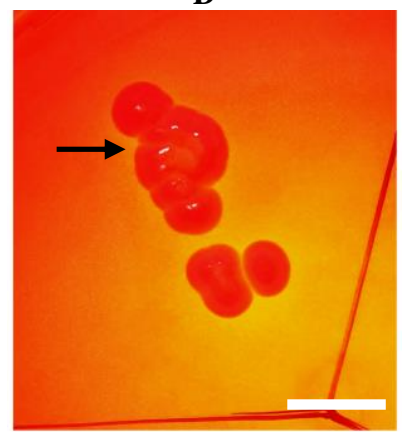

H

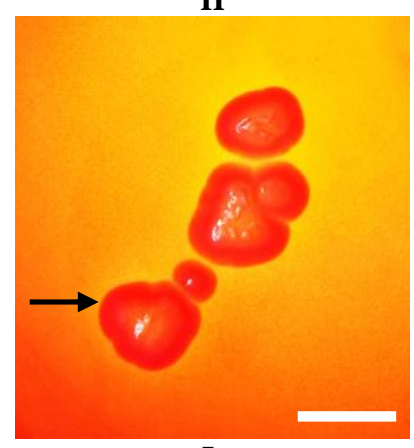

L

Figure 1. Clear zone formation in SL1-2-R-2 (a-d), SL1-2-R-3 (e-h), and SL1-2-R-4 (i-l) grown on minimal medium with addition of $0.5 \%$ xylan at temperatures of $45,50,55$, and $60^{\circ} \mathrm{C}$. Bar $=1 \mathrm{~cm}$.

Among the 17 isolates, two isolates (SL2-2-R-15 and SL3-1-R-16) were able to grow on $0.5 \%$ xylan plates, but did not show xylan-degrading ability within 7 days of incubation at temperatures of $45,50,55$, and $60^{\circ} \mathrm{C}$ (Table 1). These two isolates possibly could hydrolyze other organic components, such as agar and yeast extract in $\mathrm{Mm}$ medium as nutrients. As mentioned by Suzuki et al. (2003), agar is a polysaccharide consisting of agarose and agaropectin, and could be hydrolyzed by cleaving the $\beta-1,4$ linkage in agarose using $\beta$-agarase, producing neoagarooligosaccharides. Yeast extract is an essential organic carbon and nitrogen source for growth of microorganisms (Hakobyan et al. 2012), and it contains nucleic acid, lipid, protein, vitamins, and minerals (Chae et al. 2001).

According to Walia et al. (2017), xylanolytic activity is affected by physical parameters, such as temperature, $\mathrm{pH}$, incubation period, and nutrients contents of the culture medium. The Mm medium used in this study contained metal ionic compounds, such as $\mathrm{Mg}^{2+}$ on $\mathrm{MgSO}_{4}$ that may play a role as enzyme activator. Juturu and $\mathrm{Wu}$ (2012) mentioned that the metal ions, such as $\mathrm{Mg}^{2+}$ and $\mathrm{Ca}^{2+}$, are enzyme activators for xylanase production.

Fifteen out of $17(88 \%)$ thermophilic Actinobacteria isolates that isolated from soil of Cisolok geysers showed the xylan-degrading ability. This study suggests that thermophilic Actinobacteria isolates obtained from the soil samples of Cisolok geysers are potential producers of xylanase. They might be contributed to plant litter biomass degradation in Cisolok geysers or hot spring. Cisolok geothermal area is surrounded by vegetation of the forest with continuous litter fall which forms biomass in the geysers' area. The litter from the plant biomass might contain xylan polymers, and it might have been decomposed in the soil in Cisolok geothermal area. According to Moreira and Filho (2016), xylan is a major component of hemicellulose, which is found in plant cell walls. Thus, bacteria that possess xylanase could use it as 
an organic nutrient. According to Lee et al. (2018), Actinobacteria was one of the classes that contributed to almost $69 \%$ of the total population in the degraded foliage microbiota from foliage-rich hot spring in Sungai Klah, Malaysia, based on metagenomic analysis. Our previous studies, Mawarid et al. (2016) and Yokota et al. (2016), have reported the xylan-degrading ability of thermophilic bacteria from the phylum Firmicutes isolated from litter in Cisolok geyser, e.g. Brevibacillus sp. UICC B-76 and Paenibacillus cisolokensis $\mathrm{LC} 2-13 \mathrm{~A}^{\mathrm{T}}$, respectively. The plant litter degrading ability of the thermophilic bacteria from the phylum Firmicutes also reported by Lee et al. (2018). They found that the dominant phyla in the microbiota of degraded foliage from the deeper part of hot spring were Firmicutes and Proteobacteria.

\section{Phylogenetic tree analyses}

The taxonomic affiliation of the three potential isolates obtained from this study (SL1-2-R-2, SL1-2-R-3, and SL12-R-4) was clarified by constructing a phylogenetic tree based on the NJ, ME, and ML methods, using the Kimura two-parameter substitution model and the OTUs from their closely related species. The results of the phylogenetic analyses involving the three potential thermophilic
Actinobacteria isolates are shown in Figure 2. The three Actinobacteria isolates formed a monophyletic cluster with the type strain of their most closely related species, Actinomadura keratinilytica WCC- $2265^{\mathrm{T}}$, supported by the NJ, ME, and ML trees with $100 \%$ bootstrap values. Based on the phylogenetic species concept, the three Actinobacteria isolates (SL1-2-R-2, SL1-2-R-3, and SL12-R-4) were identified as Actinomadura keratinilytica. Sriyapai et al. (2011) and Taibi et al. (2012) reported that A. keratinilytica strains were xylanase-producing bacteria, yet there was no information of xylanolytic activity from the type strain A. keratinilytica $\mathrm{WCC}-2265^{\mathrm{T}}$. According to Sriyapai et al. (2011), Actinomadura keratinilytica S-14 was a thermophilic xylan-degrading bacterium isolated from compost, and this strain showed xylanolytic activity after being incubated at $55^{\circ} \mathrm{C}$ for 5 days. Taibi et al. (2012) reported another strain of $A$. keratinilytica, Cpt20, isolated from poultry compost, was a thermostable xylanase producer. Its xylanase demonstrated high thermostability at $60^{\circ} \mathrm{C}$ for 5 days, with 2 and $1 \mathrm{~h}$ of half-life times at 90 and $100^{\circ} \mathrm{C}$, respectively. Moreover, the xylanase produced by strain Cpt20 was affected by the presence of metal ions $\mathrm{Mn}^{2+}, \mathrm{Ca}^{2+}$, and $\mathrm{Cu}^{2+}$ and inhibited by $\mathrm{Hg}^{2+}, \mathrm{Zn}^{2+}$, and $\mathrm{Ba}^{2+}$.

\section{NJ Tree
16S rRNA}

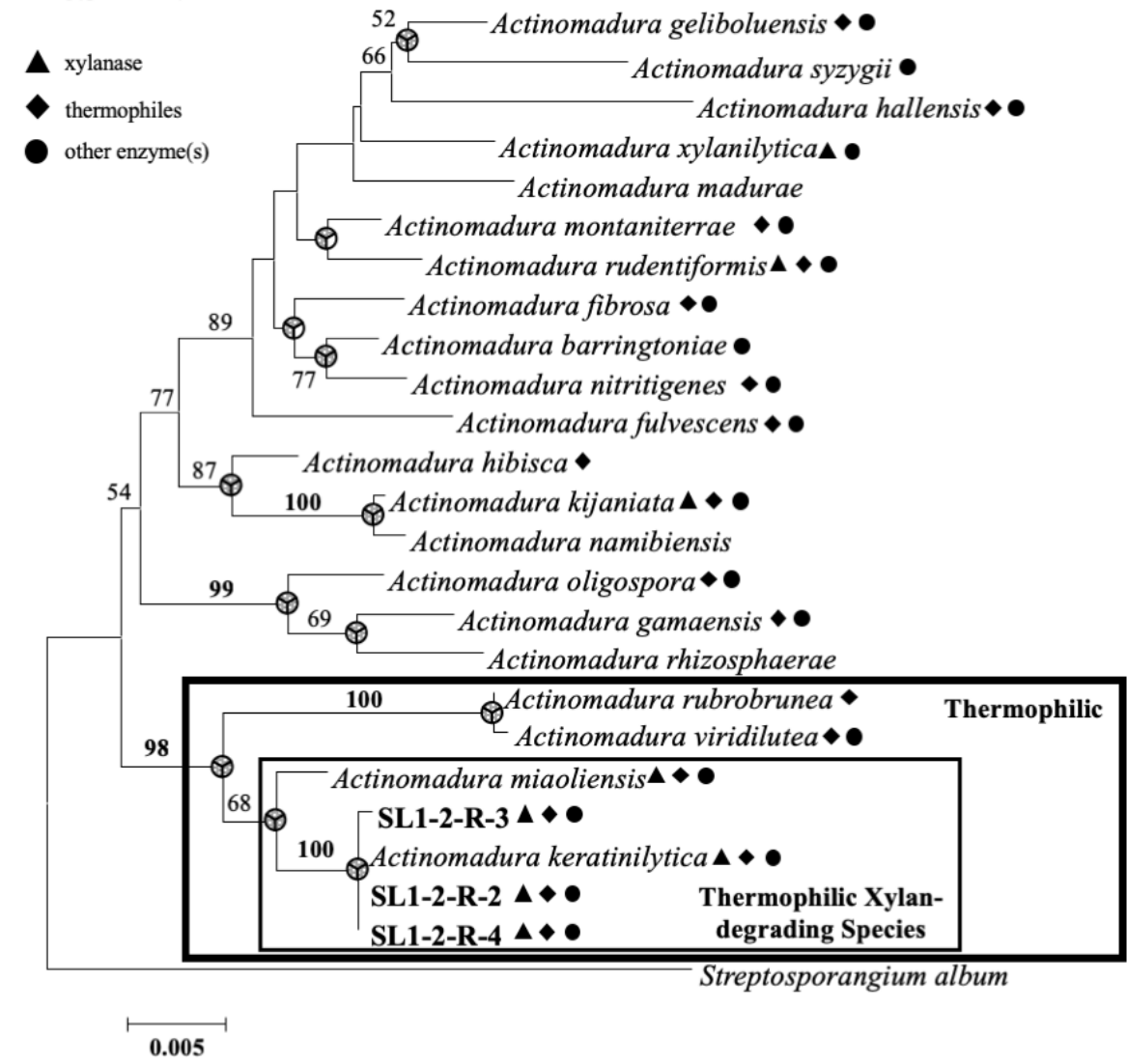

Figure 2. The neighbor-joining tree of three Actinobacteria isolates and related Actinomadura species based on 1,335 aligned positions of the 16S rRNA gene sequences. Streptosporangium album DSM $43023^{\mathrm{T}}$ was used as an outgroup. Closed circles indicate the branches of the tree that were also found using maximum likelihood and minimum evolution tree constructions. The numbers at the branch nodes represent the percentage of bootstrap values with 1,000 replicates. Only bootstrap values greater than 50\% are shown. 
Phylogenetic analyses showed that the three potential Actinobacteria isolates (SL1-2-R-2, SL1-2-R-3, and SL12-R-4), the type strain A. keratinilytica $\mathrm{WCC}-2265^{\mathrm{T}}$, and $A$. miaoliensis $\mathrm{BC} 44 \mathrm{~T}-5^{\mathrm{T}}$ formed a clade thermophilic xylandegrading species, supported by the NJ, ME, and ML methods with $68 \%$ bootstrap values (Figure 2). Other strains from these two species were also reported as xylanase-producing bacteria by Sriyapai et al. (2018) and Taibi et al. (2012). The ability of the three Actinobacteria isolates used in this study (SL1-2-R-2, SL1-2-R-3, and SL1-2-R-4) and the two Actinomadura species (A. keratinilytica and $A$. miaoliensis) to degrade xylan at high temperatures indicated their potential contribution in organic matter decomposition in nature. According to Trujillo and Goodfellow (2012), most of the Actinomadura species were soil inhabitants and played a major role in decomposition process in soil. In addition, some scientists reported that Actinomadura keratinilytica was also a potential producer of other enzymes, e.g. cellulase (Sriyapai et al. 2018), pectate lyase (Saoudi et al. 2015), keratinase (Habbeche et al. 2014), and amylase (Sukkhum et al. 2011), while A. miaoliensis was a potential producer of cellulase (Sriyapai et al. 2018). Based on this finding, the three potential isolates (SL1-2-R-2, SL1-2-R-3, and SL1-2-R-4) are potential as xylanase-producing Actinobacteria.

Three potential Actinobacteria isolates apparently formed a cluster with the thermophilic species $A$. keratinilytica $\mathrm{WCC}-2265^{\mathrm{T}}$, A. miaoliensis $\mathrm{BC} 44 \mathrm{~T}-5^{\mathrm{T}}$, A. rubrobrunea $\mathrm{NBRC} 15275^{\mathrm{T}}$, and $A$. viridilutea $\mathrm{IFO} 14480^{\mathrm{T}}$, supported by the NJ, ME, and ML methods, with $98 \%$ bootstrap values (Figure 2). Actinomadura rubrobrunea NBRC $15275^{\mathrm{T}}$ and $A$. viridilutea IFO $14480^{\mathrm{T}}$ were thermophilic species, yet their xylanolytic activities remain unknown. However, as reported by Elhoul et al. (2016), A. viridilutea was also a potential producer of keratinase.

The potential three Actinobacteria xylan-degrading isolates used in this study were obtained from soil samples collected around Cisolok geyser, indicating the soil around Cisolok geysers is a potential source of xylan-degrading Actinomadura species. According to Tseng et al. (2009), and Trujillo and Goodfellow (2012), Actinomadura miaoliensis $\mathrm{BC} 44 \mathrm{~T}-5^{\mathrm{T}}$ and $A$. rubrobrunea $\mathrm{NBRC} 15275^{\mathrm{T}}$ were also isolated from soil samples. However, some of the closely related species of these three isolates were isolated from extreme habitats, such as bovine hoof keratin bait in bovine manure compost (Actinomadura keratinilytica WCC-2265' ; Puhl et al. 2009) and desert soil (A. viridilutea IFO 14480⿱ ; Agre and Guzeva 1975).

The Actinomadura species used in the phylogenetic tree (Figure 2), were mostly isolated from soil (Tomita et al. 1989; Wink et al. 2003; Lee and Jeong 2006; Tseng et al. 2009; Trujillo and Goodfellow 2012; Zucchi et al. 2013; Zhao et al. 2015; Malisorn et al. 2018); some species were associated with plants (Rachniyom et al. 2015; Rachniyom et al. 2018); one found in biofilters consisting of tree bark compost (Songsumanus et al. 2016); and some were pathogens to animals, including humans (Trujillo and Goodfellow 2012). Information on xylanase-producing
Actinomadura species remains limited, although various species, such as A. keratinilytica Cpt20 (Taibi et al. 2012), A. miaoliensis TF1 (Sriyapai et al. 2018), A. xylanilytica BK147 ${ }^{\mathrm{T}}$ (Zucchi et al. 2013), A. rudentiformis $\mathrm{HMC1}^{\mathrm{T}}$ (le Roes and Meyers 2007), and A. kijaniata SCC $1256^{\mathrm{T}}$ (Horan and Brodsky 1982), have been reported to display xylanolytic activity. Some Actinomadura species produced other enzymes, such as cellulase (Trujillo and Goodfellow 2012, Sriyapai et al. 2018), amylase (Horan and Brodsky 1982; Lee and Jeong 2006; Sazak et al. 2012; Trujillo and Goodfellow 2012; Rachniyom et al. 2015; Zhao et al. 2015; Abagana et al. 2016; Songsumanus et al. 2016; Rachniyom et al. 2018), gelatinase (Horan and Brodsky 1982; Mertz and Yao 1986; Zucchi et al. 2013), and keratinase (Puhl et al. 2009; Trujillo and Goodfellow 2012; Habbeche et al. 2014; Elhoul et al. 2016), which demonstrated that Actinomadura species are potential enzymes producers. Most of Actinomadura species were mesophilic bacteria, which can grow well at temperatures between $25^{\circ} \mathrm{C}$ to $40^{\circ} \mathrm{C}$. However, some Actinomadura species such as $A$. formosensis, A. rubrobrunea, A. viridilutea, and $A$. keratinilytica were considered thermophiles, which grown optimally at temperatures between $45^{\circ} \mathrm{C}$ to $65^{\circ} \mathrm{C}$ (Trujillo and Goodfellow 2012).

Based on our previous study (Syafitri et al. 2019), the three isolates (SL1-2-R-2, SL1-2-R-3, and SL1-2-R-4) belong to Actinomadura keratinilytica. However, the xylanase activity from the type strain of Actinomadura keratinilytica WCC $-2265^{\mathrm{T}}$ was not yet reported. Therefore, the confirmation of xylan-degrading ability for the three potential isolates along with the type strain of Actinomadura keratinilytica $\mathrm{WCC}-2265^{\mathrm{T}}$ was conducted in this study.

\section{Xylan-degrading ability of the potential Actinobacteria isolates and type strain $A$. keratinilytica $\mathrm{NBRC} 105837^{\mathrm{T}}$}

As there was no information about the ability of the type strain Actinomadura keratinilytica NBRC $105837^{\mathrm{T}}$ $\left(=\mathrm{WCC}-2265^{\mathrm{T}}\right)$ to degrade xylan, the xylan-degrading ability of the type strain was examined in the present study. The ability of the type strain Actinomadura keratinilytica NBRC $105837^{\mathrm{T}}$ to hydrolyze xylan was examined together with the three potential isolates from this study (SL1-2-R2, SL1-2-R-3, and SL1-2-R-4). The xylan-degrading ability was examined using $0.5 \%$ xylan and $0.1 \%$ RBB-xylan as substrates at various temperatures. The result of xylandegrading ability of the three isolates (SL1-2-R-2, SL1-2R-3, and SL1-2-R-4) and the type strain A. keratinilytica NBRC $105837^{\mathrm{T}}$ in Mm medium with the addition of $0.1 \%$ RBB-xylan at temperatures of 45 to $60^{\circ} \mathrm{C}$ is shown in Figure 3 . The result of xylan-degrading ability of the type strain A. keratinilytica NBRC $105837^{\mathrm{T}}$ in $\mathrm{Mm}$ medium with the addition of $0.5 \%$ xylan at 45 to $60^{\circ} \mathrm{C}$ is shown in Figure 4.

After 3 days of incubation on $0.1 \%$ RBB-xylan plates at temperatures of 45 to $60^{\circ} \mathrm{C}$, the three isolates (SL1-2-R-2, SL1-2-R-3, and SL1-2-R-4) were confirmed for positive xylan-degrading ability (Figure 3). As mentioned by Jeffrey et al. (2011), the presence of clear zones around 
colonies on a medium containing RBB-xylan indicating the production of extracellular xylanases. In addition, a $0.1 \%$ RBB-xylan medium could be used in the preliminary screening of xylanase for actinomycetes. The RBB-xylan is a soluble chromogenic substrate used to detect endo-1,4- $\beta$ xylanase based on changes in the medium's color due to the enzymatic reactions (Brennan et al. 2004; Juturu and Wu 2012; Skovgaard and Jørgenson 2013).

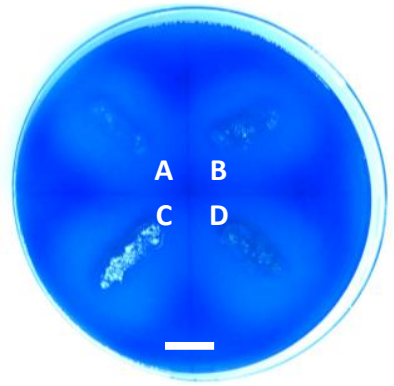

$45^{\circ} \mathrm{C}$

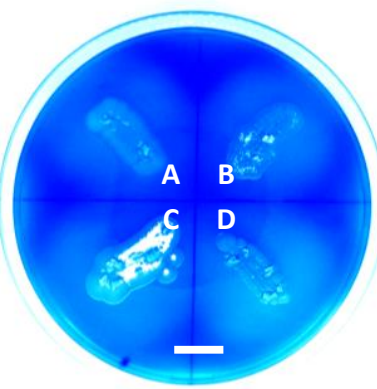

$50{ }^{\circ} \mathbf{C}$

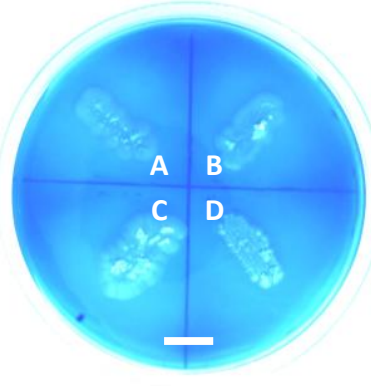

$55^{\circ} \mathrm{C}$

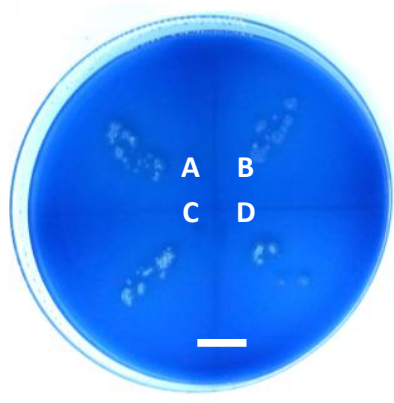

$60{ }^{\circ} \mathrm{C}$

Figure 3. Examination of xylan-degrading ability for four Actinobacteria isolates grown on minimal medium supplemented with $0.1 \%$ RBB-xylan and incubated for 3 days: A. SL1-2-R-2, B. SL1-2-R-3, C. SL1-2-R-4, and D. Actinomadura keratinilytica NBRC 105837 ${ }^{\mathrm{T}}$. Bar $=1 \mathrm{~cm}$

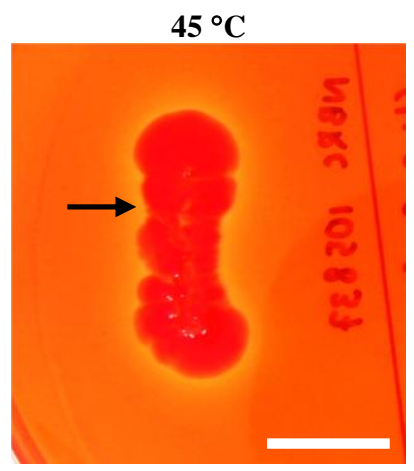

A

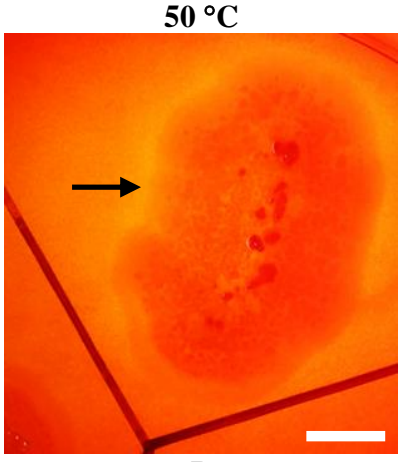

B

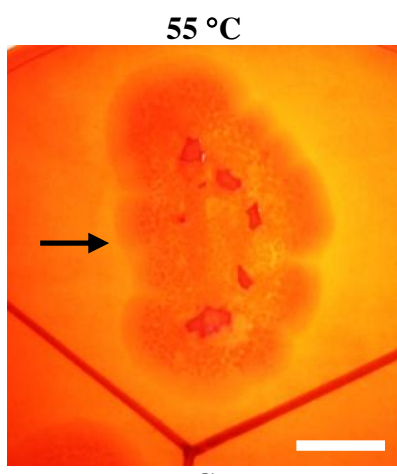

C

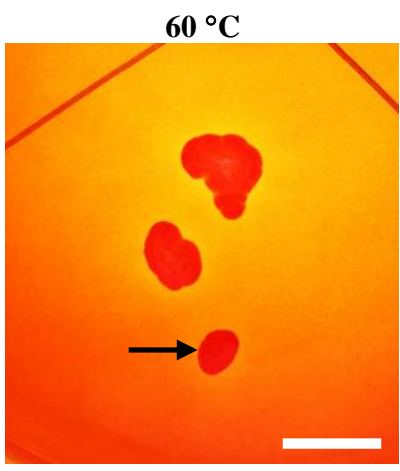

D

Figure 4. Clear zone formation in Actinomadura keratinilytica NBRC $105837^{\mathrm{T}}$ (A-D) grown on minimal medium with addition of $0.5 \%$ xylan. Bar $=1 \mathrm{~cm}$

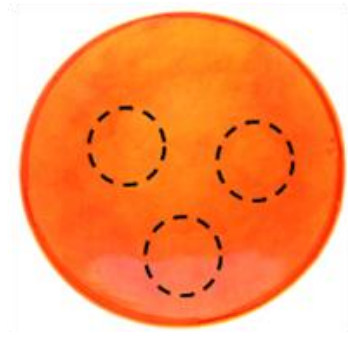

A

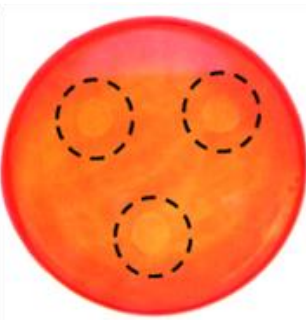

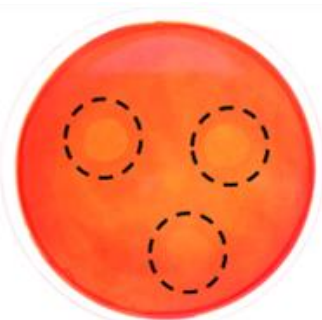

C

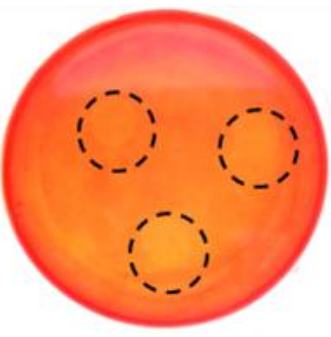

D

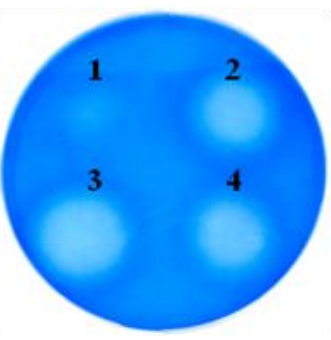

$\mathbf{E}$

Figure 5. Clear zone formation of culture supernatants containing crude xylanase from three potential isolates and type strain on Mm medium containing $0.5 \%$ xylan (A-D): A. SL1-2-R-2, B. SL1-2-R-3, C. SL1-2-R-4, D. NBRC 105837T; and E. 0.1\% RBB-xylan: (1) SL1-2-R-2, (2) SL1-2-R-3, (3) SL1-2-R-4, and (4) NBRC $105837^{\mathrm{T}}$ after incubation at $60^{\circ} \mathrm{C}$ for 24 hours. Arrow indicated clear zone. 
The ability of culture supernatants containing crude enzymes of xylanase from three potential isolates and type strain A. keratinilytica NBRC $105837^{\mathrm{T}}$ to hydrolyze $0.5 \%$ xylan and $0.1 \%$ RBB-xylan on $\mathrm{Mm}$ medium were evaluated at various temperatures $\left(45,50,55\right.$, and $\left.60^{\circ} \mathrm{C}\right)$. The crude enzymes from three potential isolates and type strain A. keratinilytica NBRC $105837^{\mathrm{T}}$ showed the ability to hydrolyzed $0.5 \%$ xylan and $0.1 \%$ RBB-xylan on $\mathrm{Mm}$ medium at various temperatures $\left(45,50,55\right.$, and $\left.60^{\circ} \mathrm{C}\right)$, indicated by the formation of clear zones. Figure 5 showed the clear zones formation of crude enzymes from three isolates and type strain at temperature of $60^{\circ} \mathrm{C}$. The results showed the culture supernatants contained extracellular xylanase that could hydrolyzed substrates at high temperatures ranging from 45 to $60^{\circ} \mathrm{C}$. McCarthy et al. (1985) reported that the increasing of incubation temperatures for culture supernatant might be associated with thermostability of xylanase.

The results of extracellular xylanase production in this study might demonstrate that xylanase production is an inducible activity in microorganisms. Seven days of incubation on $\mathrm{Mm}$ broth containing $0.5 \%$ xylan might be addressed to late growth period of cultures, thus indicating the culture might produce high quantities of xylanolytic enzymes. According to the previous studies, the production of xylanase was induced by incubating microorganism on xylan-containing medium (McCarthy et al. 1985), due to the abundant of xylan, xylose, or xylooligosaccharides on culture medium (Khucharoenphaisan et al. 2010). Xylanase production was highly associated with growth rate of actinomycetes (Dou et al. 2019), and production of extracellular endoxylanase was associated with degradation of xylan (McCarthy et al. 1985). Furthermore, study regarding the measurement of reducing sugar released from tested substrates is required to obtain the types of xylanases produced by tested microorganisms.

In addition, the cellulose-degrading ability for three potential isolates at high temperatures were also reported in the previous study. The ability of three potential isolates to produce xylanolytic and cellulolytic enzymes might indicate the possession of multicomplex xylanase-cellulase system. Setyaningsih et al. (2019) reported that the three potential isolates were able to degrade $\mathrm{CMC}$ and $\mathrm{MCC}$ as substrates at various temperatures $\left(45,50,55\right.$, and $\left.60^{\circ} \mathrm{C}\right)$ due to the production of cellulolytic enzyme. Pohlschröder et al. (1994) reported another Actinobacteria, namely Clostridium papyrosolvens $\mathrm{C} 7$ possessed multiple complexes of cellulase-xylanase system that correspond to degradation of cellulose and xylan polymers.

Our study also revealed that the type strain $A$. keratinilytica NBRC $105837^{\mathrm{T}}$ was able to grow and showed xylan-degrading ability in both $0.1 \%$ RBB-xylan (Figure 3 ) and $0.5 \%$ xylan (Figure 4 ) as substrates at temperatures of $45,50,55$, and $60^{\circ} \mathrm{C}$. According to the previous study by Puhl et al. (2009), the A. keratinilytica WCC-2265 ${ }^{\mathrm{T}}$ was able to grow at temperatures of 30 to $55^{\circ} \mathrm{C}$ with optimum growth at $45^{\circ} \mathrm{C}$. This study provides new information regarding the growth ability of the type strain $A$. keratinilytica NBRC $105837^{\mathrm{T}}$ at temperature of $60^{\circ} \mathrm{C}$ and its xylan-degrading ability at 45 to $60^{\circ} \mathrm{C}$. The study regarding the thermostability of the xylanase produced by the three potential isolates (SL1-2-R-2, SL1-2-R-3, and SL1-2-R-4) is needed to be further examined.

This study showed that the use of the Congo red staining method to detect extracellular xylanase on $\mathrm{Mm}$ medium containing $0.5 \%$ xylan formed a clear zone only around the colonies (Figure 1 and Figure 4). As shown in Figure 1 and Figure 4, the clear zone was faintly visible and thus might be difficult to observe, to distinguish, and to document. In contrast, it can be seen in Figure 3 that the result for the detection of xylan-degrading ability using the RBB-xylan showed an unambiguous clear zone around the colonies; thus, the clear zone was easier to distinguish compared with that obtained using the Congo red method. The similar results were observed by Meddeb-Mouelhi et al. (2014) while detecting the xylan-degrading ability by using Congo red staining method on minimal medium containing $0.5 \%$ xylan and $0.1 \%$ RBB-xylan. The detection of xylan-degrading ability by using Congo red staining showed an ambiguous clear zone around bacterial colonies, while the detection by using chromogenic medium showed an obvious clear zone. Thus, the use of medium plates containing RBB-xylan is promising rather than Congo red staining method for detection of xylan-degrading ability.

\section{Observation of morphological properties}

According to Barka et al. (2016), the main morphological features that characterize Actinobacteria are the presence or absence of mycelial and aerial hyphae, the mycelium color, the types of spore chains and spores, the spore chain length, and the production of melanoid pigments. Trujillo and Goodfellow (2012) reported that Actinomadura mainly formed branched non-fragmenting substrate mycelium, with an aerial mycelium that was either absent or developed with harboring arthrospores, and with straight, hooked, or irregular spirals of spore chains.

The morphological properties of three Actinobacteria isolate grown on modified Bennett's gellan after 14 days of incubation at $45^{\circ} \mathrm{C}$ are shown in Figure 6 . The three isolates (SL1-2-R-2, SL1-2-R-3, and SL1-2-R-4) produced non-fragmenting branched substrate hyphae with aerial hyphae borne directly from the substrate hyphae. The aerial hyphae differentiated into straight or flexuous spore chains (Figure 6). These morphological properties were consistent with those of $A$. keratinilytica WCC- $2265^{\mathrm{T}}$. According to Puhl et al. (2009), A. keratinilytica $\mathrm{WCC}-2265^{\mathrm{T}}$ possessed non-fragmenting with branched substrate hyphae and with branched aerial mycelia. The aerial mycelia differentiated into straight or flexuous chains of up to 15 spiny spores after $48 \mathrm{~h}$ of incubation at $45^{\circ} \mathrm{C}$ on keratin agar. Thus, the three Actinomadura keranitilytica strains in this study (SL1-2-R-2, SL1-2-R-3, and SL1-2-R-4) were xylandegrading Actinobacteria, that shared the same xylandegrading ability and morphological characters to the type strain A. keratinilytica NBRC $105837^{\mathrm{T}}$ (=WCC-2265 ${ }^{\mathrm{T}}$ ). 


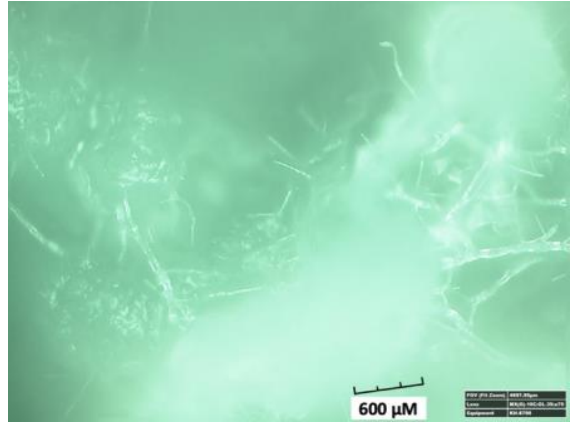

$\mathbf{A}$

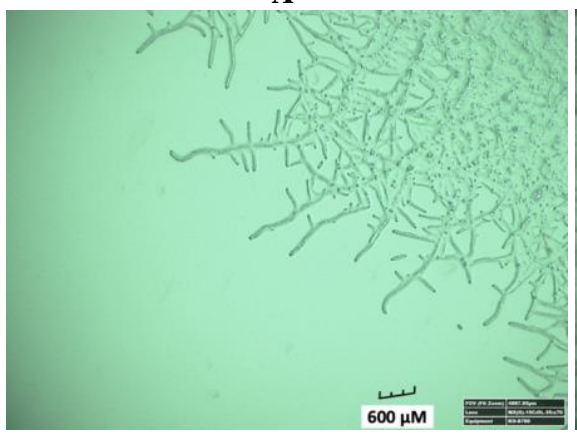

D

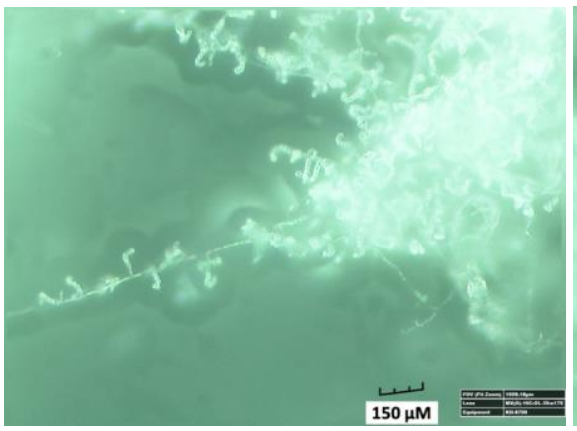

B

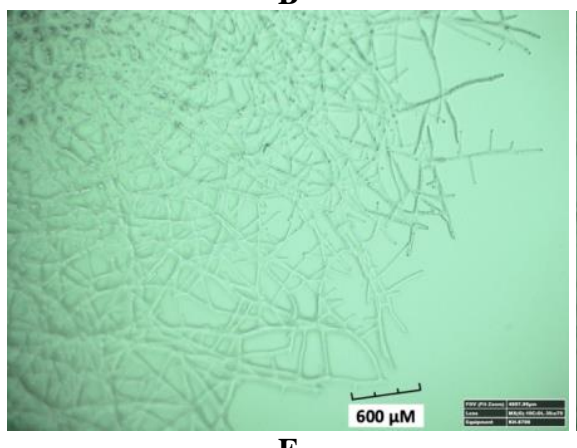

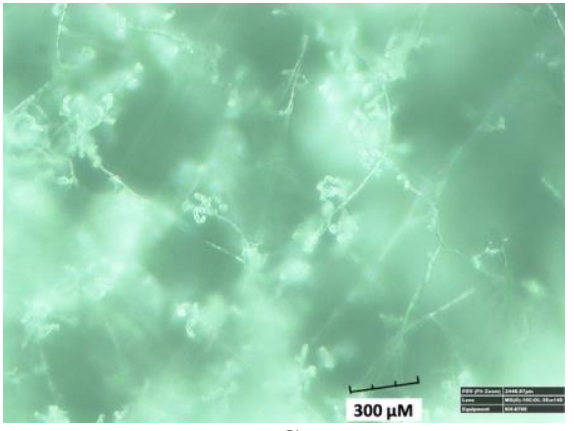

C

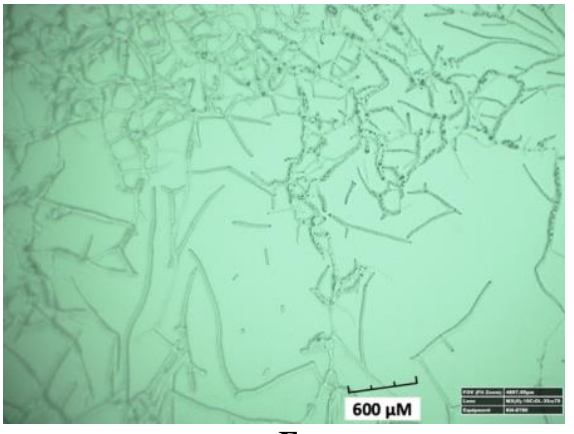

$\mathbf{F}$

Figure 6. Morphological characteristics of the three Actinomadura keratinilytica isolates after being incubated for 14 days at $45^{\circ} \mathrm{C}$. Structure of aerial mycelia on modified Bennett's gellan (A-C): A. SL1-2-R-2, B. SL1-2-R-3, C. SL1-2-R-4; structure of substrate mycelia on modified Bennett's agar (D-F): D. SL1-2-R-2, E. SL1-2-R-3, and F. SL1-2-R-4.

\section{ACKNOWLEDGEMENTS}

This study was supported by the Hibah Publikasi Internasional Terindeks untuk Tugas Akhir Mahasiswa (PITTA) UI 2018 [grant number 2331/UN2.R3.1/ HKP.05.00/2018] to W.S., by the PMDSU scholarship program [grant number NKB-3038/UN2.R3.1/ HKP.05.00/2019] from the Ministry of Research, Technology, and Higher Education of the Republic of Indonesia, and by the Tohoku University ResearchOriented Incoming Student (ROIS) 2019 Scholarship from Japan Student Services Association to M.K.R.

\section{REFERENCES}

Abagana AY, Sun P, Liu C, Cao T, Zheng W, Zhao S, Xiang W, Wang X 2016. Actinomadura gamaensis sp. nov., a novel actinomycete isolated from soil in Gama, Chad. Antonie Leeuwenhoek 109 (6): 833-839.

Agre NS, Guzeva LN. 1975. New actinomycetes genus: Excellospora gen nov. Mikrobiologiya 44 (3): 518-523.

Barka EA, Vatsa P, Sanchez L, Gaveau-Vaillant N, Jacquard C, Klenk HP, Clément C, Ouhdouch Y, van Wezel GP. 2016. Taxonomy, physiology, and natural products of Actinobacteria. Microbiol Mol Biol Rev 80 (1): 1-43.

Beg QK, Kapoor M, Mahajan L, Hoondal GS. 2001. Microbial xylanases and their industrial applications: a review. Appl Microbiol Biotechnol $56(3-4)$ : 326-338.

Brennan Y, Callen WN, Christoffersen L, Dupree P, Goubet F, Healey S, Hernández M, Keller M, Li K, Palackal N, Sittenfeld A, Tamayo G, Wells S, Hazlewood GP, Mathur EJ, Short JM, Robertson DE, Steer BA. 2004. Unusual microbial xylanases from insect guts. Appl Environ Microbiol 70 (6): 3609-3617.
Chae HJ, Joo H, In M-J. 2001 Utilization of brewer's yeast cells for the production of food-grade yeast extract. Part 1: effects of different enzymatic treatments on solid and protein recovery and flavor characteristics. Bioresour Technol 76 (3): 253-258.

Dou T-Y, Chen J, Hao Y-F, Qi X. 2019. Effects of different carbon sources on enzyme production and ultrastructure of Cellulosimicrobium cellulans. Curr Microbiol 76 (3): 355-360.

Elhoul MB, Jaouadi NZ, Rekik H, Benmrad MO, Mechri S, Moujehed E, Kourdali S, Hattab ME, Badis A, Bejar S, Jaouadi B. 2016. Biochemical and molecular characterization of new keratinoytic protease from Actinomadura viridilutea DZ50. Intl J Biol Macromol 92: 299-315.

Felsenstein J. 1981. Evolutionary trees from DNA sequences: a maximum likelihood approach. J Mol Evol 17 (6): 368-376.

Felsenstein J. 1985. Confidence limits on phylogenies: an approach using the bootstrap. Evolution 39 (4): 783-791.

Goodfellow M, Trujillo ME. 2012. Family III. Thermomonosporaceae Rainey, Ward-Rainey and Stackebrandt 1997, 486 emend. Zhang, Wang and Ruan 2001, 381 emend. Zhi, Li and Stackebrandt 2009, 600. In: Goodfellow M, Kämpfer P, Busse H-J, Trujillo ME, Suzuki K, Ludwig W, Whitman WB. (eds) Bergey's Manual of Systematic Bacteriology, 2nd ed. Springer, New York.

Goodfellow M, Williams ST. 1983. Ecology of actinomycetes. Annu Rev Microbiol 37: 189-216.

Habbeche A, Saoudi B, Jaouadi B, Haberra S, Kerouaz B, Boudelaa M, Badis A, Ladjama A. 2014. Purification and biochemical characterization of a detergent-stable keratinase from a newly thermophilic actinomycete Actinomadura keratinilytica strain Cpt29 isolated from poultry compost. J Biosci Bioeng 117 (4): 413-421.

Hakobyan L, Gabrielyan L, Trchounian A. 2012. Yeast extract as an effective nitrogen source stimulating cell growth and enhancing hydrogen photoproduction by Rhodobacter sphaeroides strains from mineral springs. Int J Hydrog Energy 37 (8): 6519-6526.

Horan AC, Brodsky BC. 1982. A Novel Antibiotic-Producing Actinomadura, Actinomadura kijaniata sp. nov. Intl J Syst Evol Microbiol 32 (2): 195-200. 
Jeffrey LSH, Norzaimawati AN, Rosnah H. 2011. Prescreening of bioactivities from actinomycetes isolated from forest peat soil of Sarawak. J Trop Agric Food Sci 39 (2): 245-253.

Jones KL. 1949. Fresh isolates of Actinomycetes in which the presence of sporogenous aerial mycelia is a fluctuating characteristic. J Bacteriol 57 (2): 141-145.

Juturu V, Wu JC. 2012. Microbial xylanases: engineering, production and industrial applications. Biotechnol Adv 30 (6): 1219-1227.

Khucharoenphaisan K, Tokuyama S, Kitpreechavanich V. 2010 Purification and characterization of a high-thermostable $\beta$-xylanase from newly isolated Thermomyces lanuginosus THKU49. Mycoscience 51 (6): 405-410

Kimura M. 1980. A simple method for estimating evolutionary rates of base substitutions through comparative studies of nucleotide sequences. J Mol Evol 16 (2): 111-120.

Kulkarni N, Shendye A, Rao M. 1999. Molecular and biotechnological aspects of xylanases. FEMS Microbiol Rev 23 (4): 411-456.

Kumar S, Stecher G, Tamura T. 2016. MEGA7: Molecular Evolutionary Genetics Analysis version 7.0 for bigger datasets. Mol Biol Evol 33 (7): 1870-1874.

Kumar V, Dangi AK, Shukla P. 2018. Engineering thermostable microbia xylanases toward its industrial applications. Mol Biotechnol 60 (3) 226-235.

le Roes M, Meyers PR. 2007. Actinomadura rudentiformis sp. nov., isolated from soil. Int J Syst Evol Microbiol 57 (1): 45-50.

Lee LS, Goh KM, Chan CS, Tan GYA, Yin W-F, Chong CS, Chan K-G. 2018. Microbial diversity of thermophiles with biomass deconstruction potential in a foliage-rich hot spring. Microbiology Open 7 (6) :e00615. DOI: 10.1002/mbo3.615

Lee SD, Jeong HS. 2006. Actinomadura hallensis sp. nov., a nove actinomycete isolated from Mt. Halla in Korea. Intl J Syst Evol Microbiol 56 (1): 259-264.

MacKenzie CR, Williams RE. 1984. Detection of cellulase and xylanase activity in isoelectric-focused gels using agar substrate gels supported on plastic film. Can J Microbiol 30 (12): 1522-1525.

Malisorn K, Kanchanasin P, Phongsopitanun W, Tanasupawat S. 2018 Actinomadura rhizosphaerae sp. nov., isolated from rhizosphere soil of the plant Azadirachta indica. Intl J Syst Evol Microbiol 68 (9): 3012-3016.

Mawarid AT, Sjamsuridzal W, Yabe S, Santoso I, Ningsih F, Nurlaili DG Oetari A, Yokota A. 2016. Polyphasic identification of a thermophilic bacterium from geyser of Cisolok, Indonesia. AIP Conf Proc 1729: 020067. DOI: $10.1063 / 1.4946970$.

McCarthy AJ, Peace E, Broda P. 1985. Studies on the extracellular xylanase activity of some thermophilic actinomycetes. Appl Microbiol Biotechnol 21 (3-4): 238-244.

Meddeb-Mouelhi F, Moisan JK, Beauregard M. 2014. A comparison of plate assay methods for detecting extracellular cellulase and xylanase activity. Enzyme Microb Technol 66: 16-19.

Mertz FP, Yao RC. 1986. Actinomadura oligospora sp. nov. the producer of a new polyether antibiotic. Intl J Syst Bacteriol 36 (2): 179-182.

Moreira LRS, Filho EXF. 2016. Insights into the mechanism of enzymatic hydrolysis of xylan. Appl Microbiol Biotechnol 100 (12): 5205-5214.

Ningsih F, Yokota A, Sakai Y, Nanatani K, Yabe S, Oetari A, Sjamsuridzal W. 2019. Gandjariella thermophila gen. nov., sp. nov., a new member of the family Pseudonocardiaceae, isolated from forest soil in a geothermal area. Intl J Syst Evol Microbiol 69 (10): 3080-3086.

Pohlschröder M, Leschine SB, Canale-Parola E. 1994. Multicomplex cellulase-xylanase system of Clostridium papyrosolvens C7. Bacteriol 176 (1): 70-76.

Puhl AA, Selinger LB, McAllister TA, Inglis GD. 2009. Actinomadura keratinilytica $\mathrm{sp}$. nov., a keratin-degrading actinobacterium isolated from bovine manure compost. Intl J Syst Evol Microbiol 59 (4): 828834.

Rachniyom H, Matsumoto A, Inahashi Y, Take A, Takahashi Y, Thamchaipenet A. 2018. Actinomadura barringtoniae sp. nov., an endophytic actinomycete isolated from the roots of Barringtonia acutangula (L.) Gaertn. Intl J Syst Evol Microbiol 68 (5): 1584-1590.

Rachniyom H, Matsumoto A, Indananda C, Duangmal K, Takahashi Y, Thamchaipenet A. 2015. Actinomadura syzygii sp. nov., an endophytic actinomycete isolated from the roots of a jambolan plum tree (Syzygium cumini L. Skeels). Intl J Syst Evol Microbiol 65 (6): 1946-1952.

Rzhetsky A, Nei M. 1992. A simple method for estimating and testing minimum-evolution trees. Mol Biol Evol 9 (5): 945-967.
Saitou N, Nei M. 1987. The neighbor-joining method: a new method for reconstructing phylogenetic trees. Mol Biol Evol 4 (4): 406-425.

Saoudi B, Habbeche A, Kerouaz B, Haberra S, Romdhane ZB, Tichati L, Boudelaa M, Belghith H, Gargouri A, Ladjama A. 2015. Purification and characterization of a new thermoalkaliphilic pectate lyase from Actinomadura keratinilytica Cpt20. Process Biochem 50 (12): 22592266

Sazak A, Camas M, Spröer C, Klenk H-P, Sahin N. 2012. Actinomadura geliboluensis sp. nov., isolated from soil. Intl J Syst Evol Microbiol 62 (8): 2011-2017.

Setyaningsih PP, Ningsih F, Rachmania MK, Syafitri WA, Sari DCAF, Yabe S, Yokota A, Oetari A, Sjamsuridzal W. 2019. Cellulolytic enzyme-producing thermophilic Actinobacteria isolated from the soil of Cisolok Geysers, West Java, Indonesia. Biodiversitas 20 (11): 3134-3141.

Shivlata L, Satyanarayana T. 2015. Thermophilic and alkaliphilic Actinobacteria: biology and potential applications. Front Microbiol 6: 1014.

Singh SP, Shukla RJ, Kikani BA. 2013. Molecular diversity and biotechnological relevance of thermophilic Actinobacteria. In: Satyanarayana T, Littlechild J, Kawarabayasi Y. (eds.). Thermophilic Microbes in Environmental and Industrial Biotechnology: Biotechnology of Thermophiles, 2nd ed. Springer, New York.

Skovgaard PA, Jørgenson H. 2013. Influence of high temperature and ethanol on thermostable lignocellulolytic enzymes. J Ind Microbiol Biotechnol 40 (5): 447-456.

Songsumanus A, Kudo T, Ohkuma M, Phongsopitanun W, Tanasupawat S. 2016. Actinomadura montaniterrae sp. nov., isolated from mountain soil. Intl J Syst Evol Microbiol 66 (9): 3310-3316.

Sriyapai P, Chansiri K, Sriyapai T. 2018. Isolation and characterization of polyester-based plastics-degrading bacteria from compost soils. Microbiology 87 (2): 290-300

Sriyapai T, Somyoonsap P, Matsui K, Kawai F, Chansiri K. 2011. Cloning of a thermostable xylanase from Actinomadura sp. S14 and its expression in Escherichia coli and Pichia pastoris. J Biosci Bioeng 111 (5): 528-536.

Sukkhum S, Tokuyama S, Kongsaeree, Tamura T, Ishida Y, Kitpreechavanich V. 2011. A novel poly (L-lactide) degrading thermophilic actinomycetes, Actinomadura keratinilytica strain T16-1 and pla sequencing. Afr J Microbiol Res 5 (18): 2575-2582.

Suzuki H, Sawai Y, Suzuki T, Kawai K. 2003. Purification and characterization of an extracellular $\beta$-agarase from Bacillus sp. MK03. J Biosci Bioeng 95 (4): 328-334

Syafitri WA, Ningsih F, Setyaningsih PP, Rachmania MK, Sari DCAF, Yabe S, Yokota A, Oetari A, Sjamsuridzal W. 2019. Screening for amylolytic activity and characterization of thermophilic Actinobacteria isolated from a Geothermal Area in West Java, Indonesia. Biodiversitas 20 (7): 1929-1938.

Taibi Z, Saoudi B, Boudelaa M, Trigui H, Belghith H, Gargouri A, Ladjama A. 2012. Purification and biochemical characterization of highly thermostable xylanase from Actinomadura sp. strain Cpt 20 isolated from poultry compost. Appl Biochem Biotechnol 166 (3): 663-679.

Tomita K, Nishio M, Saitoh K, Yamamoto H, Hoshino Y, Ohkuma H, Konishi M, Miyaki T, Oki T. 1989. Pradmicins A, B, and C: new antifungal antibiotics I. Taxonomy, production, isolation, and physicochemical properties. J Antibiot 43 (7): 755-762.

Trujillo ME, Goodfellow M. 2012. Genus III. Actinomadura Lechevalier and Lechevalier 1970a, 400 ${ }^{\mathrm{AL}}$ emend. Kroppenstedt, Stackebrandt and Goodfellow 1990, 156. In: Goodfellow M, Kämpfer P, Busse H-J, Trujillo ME, Suzuki K-I, Ludwig W, Whitman WB. (eds.), Bergey's Manual of Systematic Bacteriology, 2nd ed, Volume 5: Actinobacteria, part B. Springer, New York.

Tseng M, Yang SF, Hoang KC, Liao HC, Yuan GF, Liao CC. 2009. Actinomadura miaoliensis sp. nov., a thermotolerant polyesterdegrading actinomycete. Int J Syst Evol Microbiol 59 (3): 517-520.

Ventura M, Canchaya C, Tauch A, Chandra G, Fitzgerald GF, Chater KF, van Sinderen D. 2007. Genomics of Actinobacteria: tracing the evolutionary history of an ancient phylum. Microbiol Mol Biol Rev 71 (3): 495-548

Walia A, Guleria S, Mehta P, Chauhan A, Parkash J. 2017. Microbial xylanases and their industrial application in pulp and paper biobleaching: a review. 3 Biotech 7 (1): 11.

Wink J, Kroppenstedt RM, Seibert G, Stackebrandt E. 2003. Actinomadura namibiensis sp. nov. Intl J Syst Evol Microbiol 53 (3): 721-724. 
Yokota A, Ningsih F, Nurlaili DG, Sakai Y, Yabe S, Oetari A, Santoso I, Sjamsuridzal W. 2016. Paenibacillus cisolokensis sp. nov., isolated from litter of a geyser. Intl J Syst Evol Microbiol 66 (8): 3088-3094.

Zhao J, Guo L, Sun P, Han C, Bai L, Liu C, Li Y, Xiang W, Wang X. 2015. Actinomadura jiaoheensis sp. nov. and Actinomadura sporangiiformans sp. nov., two novel actinomycetes isolated from muddy soil and emended description of the genus Actinomadura. Antonie van Leeuwenhoek 108 (6): 1331-1339.

Zucchi TD, Kim B-Y, Bonda ANV, Goodfellow M. 2013. Actinomadura xylanilytica sp. nov., an actinomycete isolated from soil. Int J Syst Evol Microbiol 63 (2): 576-580. 